\title{
The Analysis of Basic Sentence Patterns in English Translation of the Holy Qur'an In Surah Ad Dukhan By Abdulloh Yousuf Ali
}

\author{
Arifah Wulandari \\ IAIN Salatiga \\ Jl. Tentara Pelajar No 2 Salatiga, Central Java, Indonesia \\ Arifahwulan16@gmail.com
}

\begin{abstract}
This study is aimed at the analysis of basic sentence patterns in English translation of the holy Qur'an in surah Ad Dukhan. Focusing on the problem statements, there are two cases in this study. They are "What are types of the basic sentence patterns that is found in English translation of the Holy Qur'an in surah Ad Dukhan and what is the dominant of the basic sentence patterns types that is found in English translation of the holy Qur'an in surah Ad Dukhan. This research, applied descriptive qualitative method. The data is collected by documentation. The primary data is taken from surah Ad Dukhan in Abdullah Yousuf Ali's English translation of the noble Al Qur'an. The secondary data is taken from many literary books and some relevant materials to support and complete the primary data source.

The procedure of analyzing the data start by analyzing about basic sentence patterns types based on Nichols's theory in his book English Syntax. Then find the dominant of the basic sentence patterns types of the holy Qur'an English by Abdullah Yusuf 'Ali, in 1934 that is focus in surah Ad Dukhan. The overall findings showed that there were basic sentence patterns found in 52 cases are in sentence patterns 1consist of 12 cases, in sentence patterns 2 there are 19 cases, in sentence patterns 3 there are 7 cases, in sentence patterns 4 there are 10 cases, in sentence patterns 5 there are 4 cases. From the result the dominant cases that occurred of sentence patterns that found in Abdullah Yusuf Ali's
\end{abstract}


translation. The most dominant is sentence patterns 2. After analysis in this paper, the writer suggests in analyzing basic sentence pattern of English, we find that selection is an important syntactic process. The learner will get new idea doing observe as the writer done and they can possibly provide more book to have deeper analysis about that.

Key Word: Sentence Patterns, Translation, Holy Qur'an, Surah Ad Dukhan.

\section{Abstrak}

Penelitian ini bertujuan untuk menganalisis pola kalimat dasar pada terjemahan Bahasa Inggris yanga terdapat di Al Qur'an surat Ad Dukhan. Pernyataan masalah fokus pada dua kasus dalam penelitian ini. Kasus tersebut adalah "Apa tipe-tipe pola kalimat dasar yang terdapat pada terjemahan Bahasa Inggris di dalam Al Qura'an surat Ad dukhan" and "Apakah tipe pola kalimat dasar yang sering muncul pada terjemahan Bahasa Inggris di dalam Al Qura'an surat Ad dukhan". Dalam penelitian ini menerapkan metode diskriptif kualitatif. Data dikumpulkan dengan dokumentasi. Data utama diambil dari terjemahan Bahasa Inggris dalam Al Qur'an surat Ad Dukhan yg diterjemah kan oleh Abdullah Yousuf Ali. Data kedua diambil dari beberapa buku sasatra dan beberapa buku yng relavan untuk mendukung dan melengkapi data utama.

Cara menganalisa data dimulai dengan menganalisis tentang tipe pola kalimat dasar berdasarkan teori Nichols dalam bukunya English Syntax. kemudian menemukan tipe pola kalimat dasar yang sering muncul pada terjemahan Bahasa Inggris di dalam Al Qura'an surat Ad dukhan oleh Abdullah Yousuf Ali. Temuan pada keseluruhannya menunjukkan bahwa pola kalimat dasar yang ditemukan ada 52 kasus diantaranya adalah pola kalimat tipe ke 1 terdapat 12 kasus, pada pola kalimat tipe ke 2 terdapat 19 kasus, pola kalimat tipe ke 3 terdapat 7 kasus, pola kalimat tipe ke 4 terdapat 10, dan pola kalimat tip eke 5 terdapat 4 kasus. Dari hasil tersebut kasus yang sering muncul terjadi pada pola kalimat yang ditemukan dalam terjemahan Bahasa Inggris Abdullah Yousuf Ali adalah pola jalimat tipe ke 2. Setelah menganalisis tulisan ini, penulis menganjurkan untuk menganalis pola kalimat dalam Bahasa Inggris, kita menemukan pilihan yang penting dalam proses syntactic. Para pembelajar akan mendapatkan ide baru unyuk melakukan penelitian seperti yang penulis telah lakukandan merekan mungkin memperlengkapi lebih banyak buku utuk menganalisis lebih dalam 
tentang itu.

Kata Kunci: Pola Kalimat, Terjemahan, Kitab Al Qur'an, Surah Ad Dukhan.

\section{Introduction}

Languages have rules. The rules of a language are called the grammar. The reason for these rules is that a person needs to be able to speak an indeterminately large number of sentences in a lifetime. The effort would be impossibly great if each sentence had to be learn separately. In linguistics, the way in which words are put together to form phrases, clauses, or sentences is called by syntax.

According to Miller (2002: xii), syntax has to do with how words are put together to build phrases, how phrases are put together to build clauses or bigger phrases, and how clauses are put together to build sentences. In small and familiar situations, humans could communicate using single words and many gestures, particularly when dealing with other members of the same social grouping (nuclear family, extended family, clan and so on). But complex messages for complex situations or complex ideas require more than just single words; every human language has devices with which its speakers can construct phrases and clauses.

By learning the rules for connecting words it is possible to create an infinite number of sentences, all of which are meaningful to a person who knows the syntax. Thus it is possible to construct many sentences that the speaker has never heard before. 
Language is the greatest means of communication among people which naturally tend to get closer to another language through speech. Thus, they try to overcome the barrier of language among them through translation in any of its various forms, written or spoken. In translation, the rule of the language is very important. When we translate something, we will convey the message. We need syntax in order to compose complex message because it convey meaning.

Translation has played a great role in all walks of life just like politics, diplomacy, government administration, science, technology and religious activities. Out of this vital part in communication among different peoples, cultures and races through different ages, translation has always been needed. Translation has played a great role in the development of many languages and their literatures. Translation is everywhere: in business, international politics, cultural exchange, science, technology and international organizations such as the United Nations and European Union (Newmark, 1981: 5-6; Massoud, 1988: 1-2). Translation was a necessity in the past, an urgent need at present and will be a more pressing need in the future.

In the past, Arabic language rendered thousands of Greek works in nearly all fields into their language. Comparing the Arabian world today with other European, Asian and American countries in the field of translation, it is discovered that the Arabian world lags behind all of them. In addition, Arabic language needs translation to portray a true picture about their identity and culture, and here lies the importance of translating the Qur'an, the core of their majority's religion-Islam.

There are many reasons for translating the Qur'an. According to 
the Islamic view, Islam is a universal religion, and Prophet Muhammad was sent as a Messenger to the whole world, regardless of language, color, race, etc. The universality of the Islamic message has made Muslims responsible for translating the Qur'an into different languages to "the jn greatest part of the Muslim nation, to whom Arabic has become, a foreign language" (Ghali, 2005: ix). In view of the importance of translating the Qur'an, many eminent scholars of Islam say that it is obligatory.

It is important to translate the Qur'an into different languages; the translation into English is the most important. First of all, English, as considered by many, is the first language all over the world nowadays. It is held as a language of high esteem and prestige, being the official language of many politically influential countries such as the USA and the UK and the second language of many other significant countries as China, India, etc. Besides that, English is known as a foreign language in the world, especially in Western Europe.

Moreover, a great deal of the mass media is in English. This widespread of the English language gives any English translation of the Qur'an the opportunity to be more widely read than any other translation into another language. In the Preface of the Holy Qur'an English translation entitled The Holy Qur'an: Translation and Commentary by Abdullah Yusuf 'Ali, in 1934, wrote "The English language, being widely spread, many people interested in Islam will get their ideas of the Qur'an from English translations”.

In this study, the writer chose Surah Ad-Dukhan for the discussion. The surah is chosen because there are many messages in this 
surah. The theme of this particular surah is how worldly pride and power are humbled in the dust if they resist spiritual forces, and how Evil and Good find their true setting in the Hereafter. The title of Ad Dukhan revealed in verse 10 in the Holy Qur'an. The meaning of ad Dukhan is smoke or mist and may refer to a drought or famine, as explained in the notes to the verse. It is very important to understand the whole content of this surah. We can learn it through the translation then applied the moral excellences from this surah for our daily life.

\section{Language in Translation}

Language is "the system of human expression by means of words" while literature is" a written works which are of artistic value". According to (Newmark, 1988: 127), a literary translation should be artistic and has no limited right. Moreover, as connotative, literary text should be translated to know its latent meaning, to look the allegory in the story, the moral in the action, etc. He said that the interpretation of text is able to clear up and even increase by way of translation. It is to give some perception and understanding of culture (Newmark, 1988: 19).

The relationship of linguistics to translation can be twofold: one can apply the findings of linguistics to the practice of translation, and one can have a linguistic theory of translation, as opposed, say, to a literary, economic or psychological theory of translation.

Saussure (linguist) made it possible to see language as a set of structured systems rather than a ragbag of bits and pieces. Some parts of language, such as grammar, have always been thought of as systems, of course. But the structuralism linguistics that emerged from Saussure's 
work attempted to uncover the systematic and structured nature of other parts of language: the sound system (phonetics and phonemics), the grammar system (syntax, which is word order, and morphology, which is word shape) and the meaning system (semantics).

\section{Definition of Syntax}

Syntax is concerned with the ways in which words can be combined together to form phrases and sentences. Grammar is traditionally concerned not just with the principles which determine the formation of words, phrase, and sentences, but also with principles which tell us how to interpret (= assign meaning to) words, phrases, and sentences. For example, any comprehensive grammar of English will specify that compound words like man-eater and man-made, the word man is traditionally said to have a patient interpretation, in the sense that man is the patient/hopeless victim on whom the act of eating is going to be performed; by contrast, in compounds like man-made, the word man is said to have an agent interpretation, in the sense the man is agent responsible for the act of making. Thus, structural aspects of meaning traditionally said to be part of the domain of grammar. In terms of the traditional division of grammar into morphology and syntax, we can say that morphology studies the formation and interpretation of word, where as syntax is concerned with the formation and interpretation of phrases and sentences.

\section{Sentence Patterns}

Sentence patterns can be understood as the way sentences are usually structured. It is important to learn the most common sentence 
patterns in English, as most of the sentences you will hear, write, and speak will follow these basic patterns.

There are a number of common sentence patterns used to write most sentences in English. The basic sentence patterns presented in this guide to sentence patterns will help to understand the underlying pattern in even the most complex English sentences.

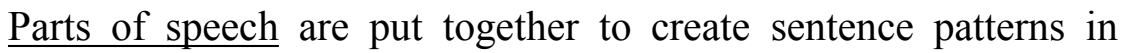
English. Quickly, the eight parts of speech are as follows: Noun, pronoun, adjective, verb, adverb, conjunction, preposition and interjection

We are all familiar with the basic sentence patterns of English. We know how to use them in their simplest forms. But sometimes when we concentrate very hard on what we want to say, or when we try to complicate one these patterns, you omit a basic sentence part, or try to combine sentence parts that cannot be fitted together. When this happens, our sentence collapses just as building would collapse if the engineers and builders omitted part of the foundation or tried to fasten two important steel girders together in the wrong places.

Here are five of the most commonly used basic sentence patterns

$\begin{array}{lcccc}\text { Bread spoils. } & \mathrm{N} & \mathrm{V} & & \\ \text { Children like bread } & \mathrm{N} & \mathrm{V} & \mathrm{N} & \\ \text { Bread is food } & \mathrm{N}_{\mathrm{X}} & \mathrm{LV} & \mathrm{N}_{\mathrm{X}} & \\ \text { Bread is nutritious } & & \mathrm{N} & \mathrm{LV} & \text { Adj } \\ \text { Bread provides mankind nutrition } & \mathrm{N}_{1} & \mathrm{~V} & \mathrm{~N}_{2} & \mathrm{~N}_{3}\end{array}$


These latter symbols will be used to designate syntactical units that are basic sentence parts: $\mathrm{N}$-nominal, $\mathrm{V}$-verbal (LV -linking verbal), Adj-adjectival. An $\mathrm{x}$ written as a subscript to $\mathrm{N}$ indicates that the nominal so marked refer to the same object or idea. Notice that bread and food could be replaced by the same pronoun, it, although in actual writing you would not replace both noun with pronouns. If more than two nominal's occur in a given pattern, as in example 5, sub numerals are used to indicate the order in which they come.

These "stripped down" sentence patterns seem a little strange partly because they are so simple. Only the basic elements are present. Mature writers seldom write this way, although such simple sentences can sometimes be very effective. The following versions of these sentences sound much more normal. But notice that the sentence patterns have not been changed. The basic sentence elements are only a little more complex: noun phrases replace single nouns, verb phrases replace single verb, adverbials modify verbs, and intensifiers modify adjectives.

- Homemade bread spoils more quickly that commercially produced bread. $\mathrm{N} \quad \mathrm{V}$

- Most children like bread and jam. N V N

- Bread is a staple food in most families. $\mathrm{N}_{X} \quad L V \quad \mathrm{~N}_{X}$

- Not all bread is equally nutritious. $\mathrm{N}_{1} \quad$ LV Adj

- Bread has been providing mankind nutrition since the beginning of time. $\mathrm{N}_{1}$ $\begin{array}{lll}\mathrm{V} & \mathrm{N}_{2} & \mathrm{~N}_{3}\end{array}$

The first thing you probably notice about these patterns is that they each have a nominal and verbal element. The verbal constituent of a 
sentence may be either singe verb or a verb phrase, as we saw in section 5. The nominal element or constituent is a little more complicated, and must be discussed in further detail before we consider the interrelationship between the basic sentence parts.

In this case, the writer would to discuss about the analysis of basic sentence patterns in English translations of Surat Ad-Dukhan (Chapter of Smoke) undertaken by 'Abdullah Yusuf 'Ali's Holy Qur'an translation. Based on the study about syntax, the writer will find some sentences then analyze them according to the types of sentences pattern

\section{Research Methodology}

In this study of "Basic Sentence Patterns in English Translation of the Holy Qur'an in surah Ad Dukhon", the writer used descriptive qualitative method. Qualitative researching was exciting and important. It was a highly rewarding activity because it engages us with things that matter, in ways that matter.

Through qualitative research we could explore a wide array of dimensions of the social world, including the texture and weave of everyday life, the understandings, experiences and imaginings of our research participants, the ways that social processes, institutions, discourses or relationships work, and the significance of the meanings that they generate. Qualitative research is descriptive because the result of the analyze data was phenomena description, not numerals about variable correlations. The qualitative researcher was said to look through a wide lens, searching for patterns of inter-relationship between a previously unspecified set of concepts. 
Qualitative research should be strategically conducted, flexible and contextual. Essentially, this means that qualitative researchers should make decisions on the basis not only of a sound research strategy, but also of sensitivity to the changing contexts and situations in which the research takes place.

\section{Research subject.}

The research subject in this study is analysis basic Sentence Patterns in "English translation of the holy Qur'an in surah Ad Dukhon"

\section{Research object.}

The research object in this study is all aspect that becomes target in the research. The object of this research is the English translation in surah Ad Dukhon" of the holy Qur'an

\section{Data source}

Primary data source

Primary data source is the essential source derived from English translation in "surah Ad Dukhon" of the holy Qur'an by Abdullah Yusuf 'Ali.

Secondary data source.

The secondary source which is used to support and complete the primary data usually was arranged into documents model the data is taken from many kinds of books relevant materials such as books of literary theories.

\section{Technique of collecting data.}

To collect the data the writer used note taking technique, a technique that prepare data trough writing on data card, then continuing by classification. The steps are: 
Collecting the data from books and academic writing that is related with this research.

Choosing one of the holy Qur'an translation model then finding surah Ad dukhan.

Reading the translation.

Try to find the theories which were support this study.

Concluding the data.

Technique of data analysis.

Based on Sudaryanto (1993:13-17) there are two kinds of methods in analyzing data of language; they are Padan method (Referential methode) and Agih method (Distributiona method). Agih method is used since the language itself becomes the determiner of the research. While Padan method is a method in which determiner is outside, unbound, and not a part of the relevant language. . The writer used Agih method (Distributiona method) to select sentence patterns in the English Translation in the surah Ad Dukhan to classifying the data and to analyze the data the writer used Disributional method. The interpretation of the text is content analysis. The steps are:

The writer reading and learning whole the English translation supported by understand all the "surah $A d$ Dukhon" of the holy Qur'an.

The writer gives an underline of English translation which 
contains the basic sentence pattern.

The writer classification of sentence pattern in English translation and make data presentation.

The writer codification types of basic sentence pattern that found in English translation.

The writer describing and analyzing types of basic sentence pattern that found in English translation

The writer making the conclusion based on the data analysis.

\section{Discussion}

The analysis of basic sentence patters in surah Ad Dukhan, the writer find based on the objective of the study. The writer finds the types of sentence patterns of sentence patterns in English Translation of surah Ad Dukhan as the following:

- Types of the basic sentence patterns

There are five basic sentence patterns according Nichols:

- Patterns 1 - Noun / Verb (N V)

This basic sentence pattern is a noun followed by a verb. It's important to remember that only verbs that do not require objects are used in this sentence pattern. There are 11 cases of sentence patterns 1 that found in surah $\mathrm{Ad}$ Dukhan. There are: in the verse (Q.S 44: 6), (Q.S 44: 9), (Q.S 44: 14), (Q.S 44: 23), (Q.S 44: 25), (Q.S 44: 27), (Q.S 44: 45), (Q.S 44: 46), (Q.S 44: 47), (Q.S 44: 55), and (Q.S 44: 59).

The example of analysis: 


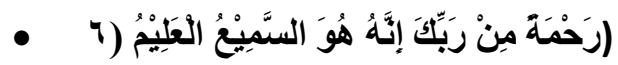

Translation: As a Mercy from thy Lord: for Hehears and knows (all things); (Q.S 44: 6)

The sentence above includes basic sentences pattern 1 because there is noun "he" that followed by verb "hears and know". There is indication of what he hears and knows, but in this verse just written in parenthesis is (all things) not described.

- Patterns 2 - Noun / Verb / Noun (N V N )

The sentence pattern 2 builds on the first pattern and is used with nouns that can take objects. There are 22 case sentence patterns 2 that found in surah Ad Dukhan. There are: in the verse (Q.S 44: 2), (Q.S 44: 3), (Q.S 44: 5), (Q.S 44: 10), (Q.S 44: 12), (Q.S 44: 15), (Q.S 44: 16), (Q.S 44: 21), (Q.S 44: 28), (Q.S 44: 29), (Q.S 44: 30), (Q.S 44: 32), (Q.S 44: 34), (Q.S 44: 37), (Q.S 44: 38), (Q.S 44: 39), (Q.S 44: 41), (Q.S 44: 48), (Q.S 44: 51), (Q.S 44: 53), (Q.S 44: 56), and (Q.S 44: 58).

The example of analysis:

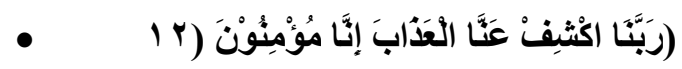

Translation: (They will say :) "아 Lord! Removethe Penalty from us for we do really believe!" (Q.S 44: 12) 
This sentence is composed of two nominal and one verbal, or subject "our lord" and predicate "remove" and used with nouns that can take objects "the penalty". This sentence can transform into derived sentence by changing the active verb into a passive verb and converting the object nominal into the subject nominal.

- Patterns 3- Noun / Linking Verb / Noun $\left(\mathrm{N}_{\mathrm{x}} \mathrm{LV} \mathrm{N}_{\mathrm{x}}\right)$

This sentence pattern uses linking verbs to link one noun to another. Linking verbs are also known as equating verbs. There are 7 case sentence patterns 3 that found in surah Ad Dukhan. There are: in the verse (Q.S 44: 13), (Q.S 44: 17), (Q.S 44: 24), (Q.S 44: 33), (Q.S 44: 40), (Q.S 44: 44), and (Q.S 44: 50).

The example of analysis:

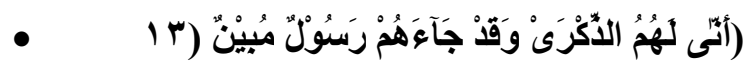

Translation: How shall the Messagebe(effectual) for them, seeing that a Messenger explaining things clearly has (already) come to them (Q.S 44: 13)

This sentence uses linking verbs to link one noun to another. Linking verbs also known as equating verb is "be". There are two nominal's refer to the same object and each can be replaced by same pronoun (message -it, effectual -it) the second nominal is simply the identification or classification of the first. 
- Patterns 4 - Noun / Linking Verb / Adjective (N LV Adj)

This sentence pattern uses linking verbs to link one noun to its description using an adjective. There are 10 case sentence patterns 4 that found in surah Ad Dukhan. There are: in the verse (Q.S 44: 4), (Q.S 44: 7), (Q.S 44: 11), (Q.S 44: 22), (Q.S 44: 31), (Q.S 44: 35), (Q.S 44: 36), (Q.S 44: 42), (Q.S 44: 35), (Q.S 44: 36), (Q.S 44: 42), (Q.S 44: 49), (Q.S 44: 57).

The example of analysis:

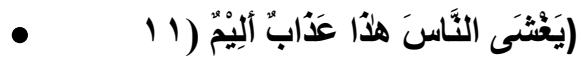

Translation:Enveloping the people: thiswill bea Penalty Grievous. (Q.S 44: 11)

\begin{tabular}{|c|c|c|c|c|c|c|}
\hline The & People & will & $\underline{\mathrm{Be}}$ & $\underline{\mathrm{a}}$ art & Penalty & Grievous \\
\hline art & $\mathbf{N}$ & $\bmod$ & LV & & $\mathbf{N}$ & Adj \\
\hline
\end{tabular}

$\mathbf{N}$

$$
\overline{\mathrm{LV}} \mathbf{N}
$$

This sentence includes sentence pattern 4, uses linking verbs to link one noun to its description using an adjective. This sentence is composed of noun (the people), linking verb (be), and adjective (a penalty grievous).

- Patterns 5 - Noun / Verb / Noun / Noun (N V N N)

Sentence pattern 5 is used with verbs that take both direct and indirect objects. There are 4 case sentence patterns 5 that found in surah Ad Dukhan. There are: in the verse (Q.S 44: 7), (Q.S 44: 17), (Q.S 44: 20), (Q.S 44: $54)$. 
The example of analysis:

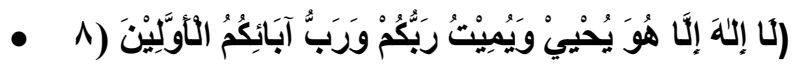

Translation: There is no god but He: it is $\underline{\mathrm{He} \text { Who }}$ giveslife and gives death -- the Lord and Cherisher to you and your earliest ancestors. (Q.S 44: 8)

This sentence includes basic sentence pattern 5 . This sentence is composed of only three nominal (he, life, and death) and one verbal (give), the third nominal is the direct object, and the second, which is the first nominal following the verb is the indirect object.

- The dominant types of sentence patterns in English Translation of surah Ad Dukhan.

The analysis show that sentence patterns found in 52 cases are in sentence patterns 1 consist of 12 cases, in sentence patterns 2 there are 19 cases, in sentence patterns 3 there are 7 cases, in sentence patterns 4 there are 10 cases, in sentence patterns 5 there are 4 case. Te most dominant is sentence patterns 2

\section{Conclusion}

After analyzing the basic sentence patters in surah Ad Dukhan, the writer concludes based on the objective of the study. The writer finds the types of sentence patterns and finds the dominant types of sentence patterns in English Translation of surah Ad Dukhan as the following:

- $\quad$ Types of the basic sentence patterns 
There are five basic sentence patterns according Nichols:

\section{Patterns 1 - Noun / Verb (N V)}

This basic sentence pattern is a noun followed by a verb. It's important to remember that only verbs that do not require objects are used in this sentence pattern. There are 11 cases of sentence patterns 1 that found in surah $\mathrm{Ad}$ Dukhan. There are: in the verse (Q.S 44: 6), (Q.S 44: 9), (Q.S 44: 14), (Q.S 44: 23), (Q.S 44: 25), (Q.S 44: 27), (Q.S 44: 45), (Q.S 44: 46), (Q.S 44: 47), (Q.S 44: 55), and (Q.S 44: 59)

Patterns 2 - Noun / Verb / Noun (N V N )

The sentence pattern 2 builds on the first pattern and is used with nouns that can take objects. There are 22 case sentence patterns 2 that found in surah Ad Dukhan. There are: in the verse (Q.S 44: 2), (Q.S 44: 3), (Q.S 44: 5), (Q.S 44: 10), (Q.S 44: 12), (Q.S 44: 15), (Q.S 44: 16), (Q.S 44: 21), (Q.S 44: 28), (Q.S 44: 29), (Q.S 44: 30), (Q.S 44: 32), (Q.S 44: 34), (Q.S 44: 37), (Q.S 44: 38), (Q.S 44: 39), (Q.S 44: 41), (Q.S 44: 48), (Q.S 44: 51), (Q.S 44: 53), (Q.S 44: 56), and (Q.S 44: 58).

\section{Patterns 3- Noun / Linking Verb / Noun $\left(\mathrm{N}_{\mathrm{x}} \mathrm{LV} \mathrm{N}_{\mathrm{x}}\right)$}

This sentence pattern uses linking verbs to link one noun to another. Linking verbs are also known as equating verbs. There are 7 case sentence patterns 3 that found in surah Ad Dukhan. There are: in the verse (Q.S 44: 13), 
(Q.S 44: 17), (Q.S 44: 24), (Q.S 44: 33), (Q.S 44: 40), (Q.S 44: 44), and (Q.S 44: 50).

\section{Patterns 4 - Noun / Linking Verb / Adjective (N LV Adj)}

This sentence pattern uses linking verbs to link one noun to its description using an adjective. There are 10 case sentence patterns 4 that found in surah Ad Dukhan. There are: in the verse (Q.S 44: 4), (Q.S 44: 7), (Q.S 44: 11), (Q.S 44: 22), (Q.S 44: 31), (Q.S 44: 35), (Q.S 44: 36), (Q.S 44: 42), (Q.S 44: 35), (Q.S 44: 36), (Q.S 44: 42), (Q.S 44: 49), (Q.S 44: 57).

\section{Patterns 5 - Noun / Verb / Noun / Noun (N V N N)}

Sentence pattern 5 is used with verbs that take both direct and indirect objects. There are 4 case sentence patterns 5 that found in surah Ad Dukhan. There are: in the verse (Q.S 44: 7), (Q.S 44: 17), (Q.S 44: 20), (Q.S 44: 54).

The finding of the analysis show that sentence patterns found in 52 cases are in sentence patterns 1 consist of 12 cases, in sentence patterns 2 there are 19 cases, in sentence patterns 3 there are 7 cases, in sentence patterns 4 there are 10 cases, in sentence patterns 5 there are 4 case. From the result the dominant cases that occurred of sentence patterns that found in Abdullah Yusuf Ali translation. The most dominant is sentence patterns 2. Because Subject - verb - object is the most common order by number of speakers, and the second most common order by number of known languages. 


\section{References}

Ali, Abdullah Yousuf. (1934). The Glorious Qur'an Translation and Commentary.Lebanon: Beirut.

Arikunto, Suharsimi. (1998). ProsedurPenelitian.Jakarta: RinekaCipta.

Azar, Betty Schducatrampfer. (1999). Understanding and Using English Grammar Third Edition.Pearson Education. USA

Chomsky, Noam, (1965). Aspect of the Theory of Syntax, M.I.T. Press, Cambridge, Massachusetts.

Denffer, Ahmad von. (1994). Ulum Al-Qur'an :An Introduction to the Sciences of the Qur'an. Islamic Fondation.

Fawcett, Peter. (2003). Translation and Language.Manchester, UK \& Northampton, MA.

Frank, Marcella. (1972). Modern English: a Practical Reference Guide. New York: University

Hornby, AS. (1974). Oxford Advanced Learner's Dictionary of Current English: Walton Street. University Press

Lyons, John., (1968). Introduction to Theoretical Linguistics.Cambridge University.

Miller, Jim (2002). An Introduction to English Syntax.Edinburgh University Press. Edinburgh Press, New York

Newmark, Peter. (1988). Approaches to translation.Hert ford shire; prentice hall international (U K) Ltd.

Nida E.Y Taber ch. (1974).The theory and practice of translating. Brill,Leiden

Nichols, AanEljenholm. (1965). English Syntax Advanced Composition for Native Speaker.Los Angeles State College. USA 
Radford, A. (1997). Syntax: A Minimalist Introduction. Cambridge University Press. New York.

R.Mason, Jennifer. (2002). Qualitative Researching second edition. London: SAGE Publications.

Sadiq, Saudi. (2010). A Comparative Study of Four English Translations of Surat Ad-Dukhan on the Semantic Level. Cambridge Scholars

Sudaryanto.(1993). Metode dan Aneka Teknik Analisis Bahasa.Yogyakarta.Duta Wacana University Press.

https://eg.wikipedia.org/wiki/Ad-Dukhan (Retrieved on Friday, August $\left.07^{\text {th }} 2015\right)$

http://memorizejuzamma.com/Juz\%20Amma/3.Tafsir/Tafsir\%20Ibn\%20 Kathir/044\%20Dukhan.htm (Retrieved on Friday, August $07^{\text {th }}$ 2015)

http://esl.about.com/od/writingintermediate/a/sentence patterns.htm (Retrieved on Friday, August 07 ${ }^{\text {th }}$ 2015) 
The Analysis of Basic Sentence Patterns in English Translation of the Holy Qur'an In Surah Ad Dukhan By Abdulloh Yousuf Ali 